\title{
Changes in Allergenicity of Porcine Serum Albumin by Gamma Irradiation
}

\author{
Koth-Bong-Woo-Ri Kim, So-Young Lee ${ }^{1}$, Eu-Jin Song, Jin-Gyu Park' ${ }^{2}$ Ju-Woon Lee ${ }^{2}$, \\ Myung-Woo Byun ${ }^{2}$, Kyu-Earn $\mathrm{Kim}^{3}$, and Dong-Hyun Ahn* \\ Department of Food Science and Technology/Institute of Food Science, \\ Pukyong National University, Busan 608-737, Korea \\ ${ }^{\prime}$ Traditional Food Research Group, Korea Food Research Institute, Seongnam 463-746, Korea \\ ${ }^{2}$ Radiation Food Science and Biotechnology, Advanced Radiation Technology Institute, \\ Korea Atomic Energy Research Institute, Jeongup 580-185, Korea \\ ${ }^{3}$ Department of Pediatrics and Institute of Allergy, Yonsei University College of Medicine, Seoul 120-752, Korea
}

\begin{abstract}
Pork is an excellent source of essential nutrients such as protein. However, pork can trigger hypersensitivity and serum albumin of pork is known as major allergen. In this study, to evaluate the effect of gamma irradiation on the allergenicity of porcine serum albumin (PSA), PSA solution was irradiated at 3, 5, 7, 10, 15, and $20 \mathrm{kGy}$. The changes in the ability of PSA to bind IgG and patient's serum caused by gamma irradiation were observed by ci-ELISA and immunoblotting. SDS-PAGE was used for measuring the conformational change of gamma-irradiated PSA. The ability of 3-kGy-irradiated PSA to bind p-IgG and patient's serum was decreased to $30 \%$ and $15 \%$, respectively. The binding ability showed no significant differences among all irradiated samples. SDS-PAGE showed that the irradiated PSA bands were degraded and aggregated. Immunoblotting of irradiated PSA revealed that IgG and patient's serum were rarely recognized at $3 \mathrm{kGy}$. Therefore, gamma irradiation could be applied to less-allergenic pork products.
\end{abstract}

Key words: porcine serum albumin, allergenicity, gamma irradiation

\section{Introduction}

Studies of meat allergy are rare compared to common food allergies such as cow's milk, shrimp, and peanuts (Fiocchi et al., 1998; Kanny et al., 1998; Kim et al., 2008) because meat is less allergenic than common allergy-inducing foods. But, meat and its products are important foods because it is rich in protein and participates in the development of children's gastrointestinal mucosa. Thus, studies of meat allergy have become crucial for allergic subjects.

Meat allergy has been mostly studied in children in association with cow's milk and beef allergy (Fiocchi et al., 1995; Han, 2006). Although pork allergy is relatively rare and has not been studied well, the symptoms of pork allergy manifest as atopic dermatitis and oral allergy syndrome (OAS) (Johansson et al., 2001). The prevalence of

\footnotetext{
*Corresponding author : Dong-Hyun Ahn, Department of Food Science and Technology, Pukyong National University, Daeyeon Dong, Busan 608-737, Korea. Tel: 82-51-629-5831, Fax: 8251-629-5824, E-mail: dhahn@pknu.ac.kr
}

pork allergy was found to be $58 \%$ among 57 subjects with suspected meat allergy in USA (Ayuso et al., 1999) and 3\% based on questionnaire study in Japan (Iikura et al., 1999). Also, the frequency of sensitization in the skin prick test (SPT) to pork was shown to be $2 \%$ in Germany (Bohler et al., 2001). In Korea, incidence of pork allergy showed $91.2 \%$ at $0-3$ ages groups and $54.2 \%$ at $4-6$ ages groups as a results of IgE tests (Moon et al., 2007). Serum albumins are well known as the most important meat allergen and are found in protein of milk (Wahn et al., 1981; Restani et al., 1995) and pet hair/dander (Spitzauer et al., 1997; Spitzauer et al., 1995). Most allergen of pork is serum albumin (PSA) and besides serum albumin, several other IgE-binding proteins $(60,50$ and $44 \mathrm{kDa}$ ) have been detected in pork (Wang et al., 2002; Llatser et al., 1998).

Irradiation technique is known to enhance shelf-life and/or improve microbiological safety of raw and processed food materials without damaging nutritional quality (WHO, 1999). Also, effects of gamma irradiation on allergenicity or antigenicity of food allergens have been evaluated in recent years. Some papers have indicated 
that gamma irradiation could alter conformational structure of antigen by radicals generated from radiolysis of water (Byun et al., 2000; Kume and Matsuda, 1995). For instance, Byun et al. (2000) reported that amount of shrimp heat stable protein (HSP) showed a decrease and that its antigenicity decreased in a dose-dependent manner as HSP was broken down and coagulated by gamma irradiation. Presently, in our country, few studies are reported to reduce the allergenicity of PSA, pork major allergen. Therefore, the aim of this study was to investigate changes in allergenicity and structure of PSA by gamma irradiation.

\section{Materials and Methods}

\section{Antigen and antibody}

Antigen, porcine serum albumin (PSA), was purchased from Sigma (Sigma Chemical Co., St Louis, MO, USA). Goat polyclonal-IgG was obtained from Bethyl (Bethyl laboratories Inc., Texas, USA). Serum of allergic patient to pork was obtained from Yonsei University College of Medicine. Anti-goat IgG peroxidase conjugate was purchased from Sigma (Sigma Chemical Co., St Louis, MO, USA).

\section{Ci-ELISA (competitive indirect-enzyme linked im- munosorbent analysis)}

The modified ci-ELISA method of Lee et al. (1998a) was conducted to investigate the allergenicity of physically treated PSA. Ten $\mu \mathrm{g} / \mathrm{mL}$ PSA in $0.2 \mathrm{M}$ bicarbonate buffer (pH 9.6) was coated into the wells (Nunc, Kamstrupvej, Denmark) at $4^{\circ} \mathrm{C}$, overnight and blocked for $2 \mathrm{~h}$ at $37^{\circ} \mathrm{C}$ with $1 \%$ gelatin in $0.01 \mathrm{M}$ PBS (phosphate buffered saline, $\mathrm{pH}$ 7.3). Fifty microliters of non- and physically treated PSA solution $(12 \mu \mathrm{g} / \mathrm{mL})$ and $50 \mu \mathrm{L}$ of diluted $\mathrm{p}-\operatorname{IgG}(1: 500)$ /patient's serum (1:32) in $0.01 \mathrm{M}$ PBS (pH 7.3) were added into the wells and incubated for $2 \mathrm{~h}$ at $37^{\circ} \mathrm{C}$. One hundred microliters of diluted secondary antibody (anti-goat IgG-1:40,000, anti-human IgE-1:250) were added into the wells and incubated for $2 \mathrm{~h}$ at $37^{\circ} \mathrm{C}$. One hundred microliters of phosphate citrate buffer $(\mathrm{pH}$ 5) containing $0.05 \% O$-phenylenediamine (Sigma Chemical Co.) and $0.04 \% \mathrm{H}_{2} \mathrm{O}_{2}$ was added to the wells and incubated for $30 \mathrm{~min}$ at $37^{\circ} \mathrm{C}$ and stopped by $50 \mu \mathrm{L}$ of 2 $\mathrm{M} \mathrm{H}_{2} \mathrm{SO}_{4}$. Absorbance was measured at $490 \mathrm{~nm}$ using the ELISA reader (Model 550, Bio-rad, USA). For 100\% binding between coated antigen and primary antibody, 50 $\mu \mathrm{L}$ of each primary antibody and 0.01 M PBS ( $\mathrm{pH} 7.3$ ) were added to the well. One hundred microliters of 0.01
M PBS (pH 7.3) was used as the blank. After incubation, each step was washed three times in $0.01 \mathrm{M}$ PBST $(0.01$ M PBS containing $0.05 \%$ (v/v) Tween 20). The binding ability of physically treated PSA to p-IgG and patient's serum was calculated as below.

\author{
Binding ability (\%) \\ $=$ Absorbance of physically treated PSA \\ /Absorbance of untreated PSA $\times 100$
}

\section{Titration curve of ci-ELISA}

To evaluate the degree of maximum binding between coated antigen and antibody, the modified titration curve method of Lee et al. (1998b) was carried out. Each PSA dilution $(5,10$, and $20 \mu \mathrm{g} / \mathrm{mL})$ in $0.2 \mathrm{M}$ bicarbonate buffer ( $\mathrm{pH}$ 9.6) was coated into the well at $4^{\circ} \mathrm{C}$, overnight and blocked in $0.01 \mathrm{M}$ PBS (pH 7.3) containing $1 \%$ gelatin for $2 \mathrm{~h}$ at $37^{\circ} \mathrm{C}$. One hundred microliters of diluted $\mathrm{p}$ IgG ( 2 to $0.0156 \mu \mathrm{g} / \mathrm{mL}$ ) was added to the wells and incubated for $2 \mathrm{~h}$ at $37^{\circ} \mathrm{C}$. All subsequent procedures were the same as the method of the ci-ELISA described.

\section{Standard curve of ci-ELISA}

The well was coated with $10 \mu \mathrm{g} / \mathrm{mL}$ of PSA solution in $0.2 \mathrm{M}$ bicarbonate buffer ( $\mathrm{pH} 9.6$ ) at $4^{\circ} \mathrm{C}$, overnight. The well was then blocked with $1 \%$ gelatin in $0.01 \mathrm{M}$ PBS (pH 7.3) for $2 \mathrm{~h}$ at $37^{\circ} \mathrm{C}$. Fifty microliters of 200 to 0.195 $\mu \mathrm{g} / \mathrm{mL}$ of PSA solution and $50 \mu \mathrm{L}$ of diluted $\mathrm{p}-\mathrm{IgG}$ (1:500) in 0.01 M PBS were added to the well. The following steps and conditions for the experiments were the same as method of the ci-ELISA described.

\section{Gamma irradiation treatment}

The PSA solution was transferred into a cobalt-60 irradiator (IR-79, Nordion International Ltd., Ontario, Canada) with 100 -KiloCurie activity at $10 \pm 0.5^{\circ} \mathrm{C}$ and irradiated at a dose rate of $10 \mathrm{kGy} / \mathrm{h}$. The applied dose levels were $3,5,7,10,15$, and $20 \mathrm{kGy}$.

\section{SDS-PAGE (sodium dodecyl sulfate-polyacrylamide gel electrophoresis)}

SDS-PAGE was carried out by the method of Laemmli (1970) to determine the degree of PSA decomposition by gamma irradiation. Twelve $\mu \mathrm{g} / \mathrm{mL}$ of PSA solution was used as the SDS-PAGE sample. SDS-PAGE was performed with a $12 \%$ running gel and $4.5 \%$ stacking gel. The gels were stained with CBB (coomassie brilliant blue R250) solution and destained with 5\% methanol and 7\% acetic acid solution. Molecular weight (Mw) markers 
were purchased from BioLabs (P7702S, New England BioLabs, Beverly, Massachusetts, USA). The Mw standards were insulin $\mathrm{A}$ and $\mathrm{B}$ chains $(2.3 \mathrm{kDa}$ and $3.4 \mathrm{kDa}$, respectively), aprotinin (6.5 $\mathrm{kDa})$, lysozyme (14 kDa), trypsin inhibitor $(20 \mathrm{kDa})$, triosephosphate isomerase $(26$ $\mathrm{kDa})$, lactate dehydrogenase $(36 \mathrm{kDa}), \mathrm{MBP}_{2}(42 \mathrm{kDa})$, glutamic dehydrogenase $(55 \mathrm{kDa})$, serum albumin (66 $\mathrm{kDa}$ ), phosphorylase b (97 kDa), $\beta$-galactosidase (116 $\mathrm{kDa}), \mathrm{MBP}-\beta$-galactosidase (158 kDa), and myosin (212 $\mathrm{kDa}$ ). A scanner (Power Look III, Amersham Pharmacia Biotech Company, Piscataway, New Jersey, USA) was used to analyze the gel.

\section{Immunoblotting}

After electrophoresis, electrotransfer of separated polypeptides onto methanol-activated polyvinylidene difluoride (PVDF) membrane was carried out by the method of Towbin et al. (1979). The protein was transferred for $5 \mathrm{~h}$ at $150 \mathrm{~mA}$ using a buffer containing $0.25 \mathrm{M}$ Tris-base, $1.92 \mathrm{M}$ Glycine, and 20\% Methanol. After transfer, the protein band was identified by $0.1 \%(\mathrm{w} / \mathrm{v})$ Ponceau-S and $5 \%$ acetic acid and destained with 7\% acetic acid. Each strip was blocked with $3 \%$ gelatin solution (3\% gelatin, $0.2 \mathrm{M}$ Tris-HCl buffer ( $\mathrm{pH} 7.5), 1.5 \mathrm{M} \mathrm{NaCl}$ ) for $1 \mathrm{~h}$ and incubated with diluted p-IgG (1:500)/patient's serum $(1: 30)$ in $1 \%$ gelatin solution $(1 \%$ gelatin, $0.2 \mathrm{M}$ Tris- $\mathrm{HCl}$ buffer ( $\mathrm{pH} 7.5), 1.5 \mathrm{M} \mathrm{NaCl}$ ) for $3.5 \mathrm{~h}$. The strip was incubated with diluted anti-goat/human $\mathrm{IgG} / \mathrm{IgE}$ (1:1000) in TBST (Tris-buffered saline containing $0.1 \%(\mathrm{v} / \mathrm{v})$ tween 20) for $1 \mathrm{~h}$. The protein was visualized with DAB solution (3,3'-diaminobenzidine, Sigma Co.) and rinsed with deionized water. The blots were scanned on a scanner (Power Look III, USA). Except for the blocking step, all steps were washed out three times with TBST.

\section{Statistical analysis}

Data were analyzed by ANOVA for significance using SAS software (SAS Institute Inc., Cary, NC, USA). Mean comparisons were done with Duncan's multiple range test $(p<0.05)$ to determine significant differences between sample means.

\section{Results and Discussion}

\section{Standard curve}

The concentration of PSA in the sample solutions to p$\mathrm{IgG}$ was calculated using the equation when the standard curve was obtained using $10 \mu \mathrm{g} / \mathrm{mL}$ of antigen and $2 \mu \mathrm{g} /$ $\mathrm{mL}$ of $\mathrm{p}-\mathrm{IgG}$. And the concentration of PSA in the sample solutions to serum from allergic patient to pork was calculated using the equation when the standard curve was obtained with $10 \mu \mathrm{g} / \mathrm{mL}$ of antigen and 1:32 dilution of pig-allergic patient's serum.

$$
\begin{aligned}
& x=e^{\left(\frac{2.0628-y}{0.3045}\right)} \\
& \begin{array}{l}
x=\text { concentration of PSA to goat } \mathrm{p}-\mathrm{IgG} \\
y=\text { absorbance value }
\end{array} \\
& x=e^{\left(\frac{0.9976-y}{0.2626}\right)} \\
& x=\text { concentration of PSA to serum from allergic patient } \\
& \quad \text { to pork } \\
& y=\text { absorbance value }
\end{aligned}
$$

The PSA solution to $\mathrm{p}-\operatorname{IgG}$ was quantitatively determined in the range 0.78 to $200 \mu \mathrm{g} / \mathrm{mL}$ (Fig. 1) and the PSA solution to serum from allergic patient to pork was quantitatively determined in the range 0.012 to $3.13 \mu \mathrm{g} /$ $\mathrm{mL}$ (Fig. 2).

\section{SDS-PAGE and Immunoblotting patterns of gamma-irradiated PSA}

SDS-PAGE patterns of gamma-irradiated PSA at doses of 3 to $20 \mathrm{kGy}$ are shown in Fig. 3. The gamma-irradiated PSA band (66 kDa) degraded into low-molecular-weight molecules and slightly aggregated to form high-molecular-weight molecules (lane 2 to 7 ) as compared with intact PSA band. At a dose of $20 \mathrm{kGy}$ (lane 7), degraded fragments disappeared more in comparison with those at doses ranging from 3 (lane 2) to $15 \mathrm{kGy}$ (lane 6). The structural change of food protein by radiation is induced

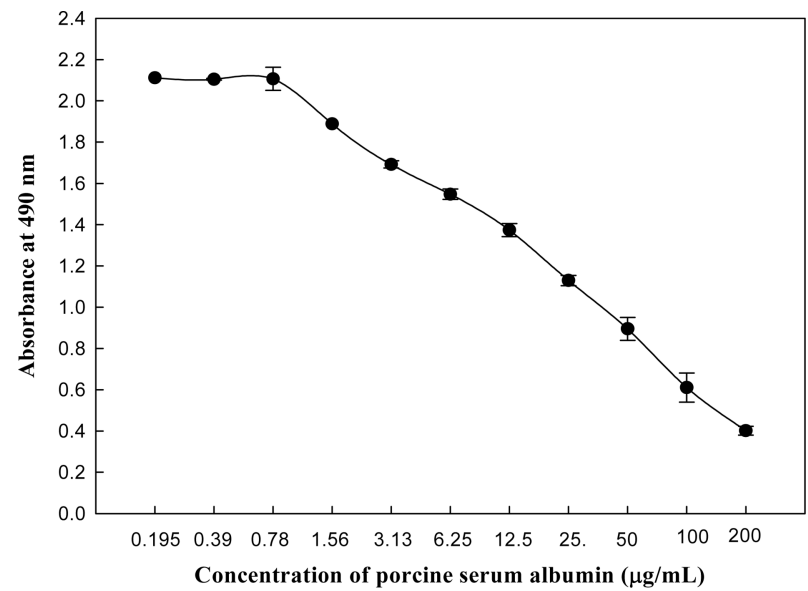

Fig. 1. Standard curve of goat p-IgG to porcine serum albumin (PSA) by Ci-ELISA. PSA was used as a coating Ag. Goat $\mathrm{p}-\mathrm{IgG}$ was used for capturing PSA. 


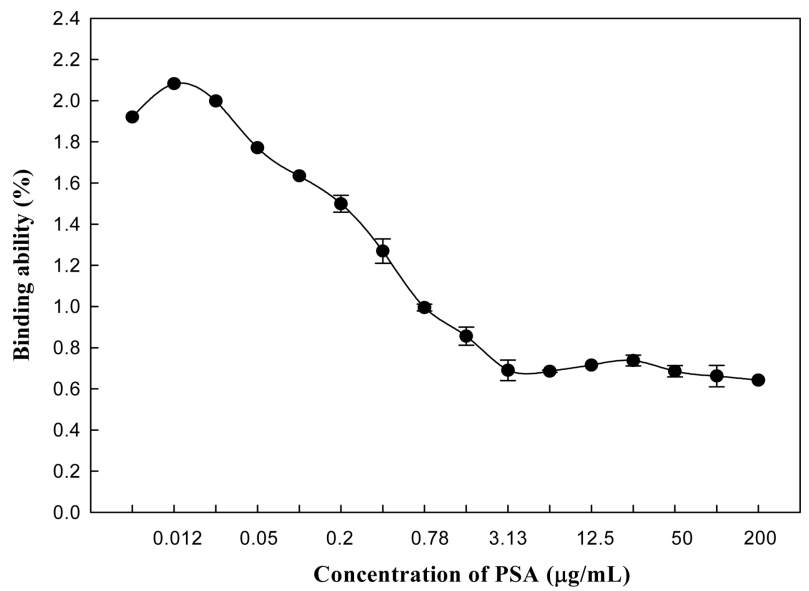

Fig. 2. Standard curve of pig-allergic patient's serum to porcine serum albumin (PSA) by Ci-ELISA. PSA was used as a coating Ag. Pig-allergic patients' serum was used for capturing PSA. (a)

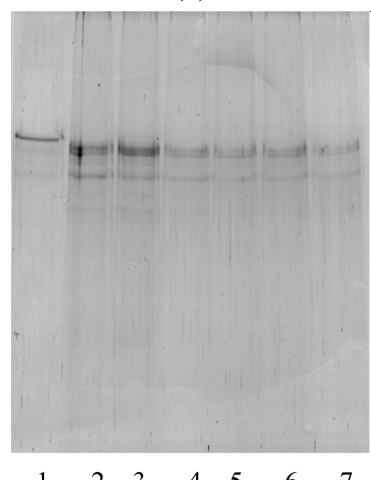

$\begin{array}{lllllll}1 & 2 & 3 & 4 & 5 & 6 & 7\end{array}$ (b)

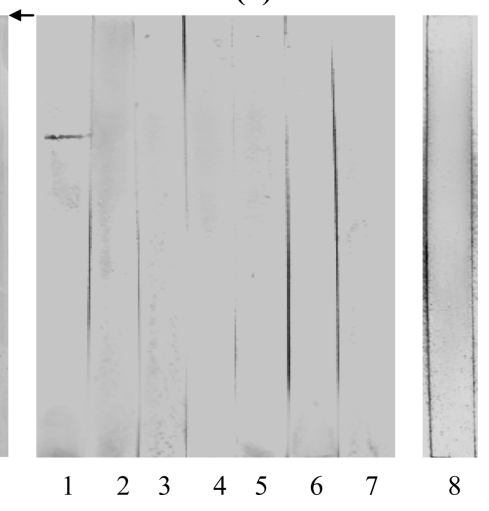

Fig. 3. SDS-PAGE (a) and immunoblot (b) of PSA treated with gamma irradiation. Numbers (1) untreated PSA, (2) $3 \mathrm{kGy}$, (3) $5 \mathrm{kGy}$, (4) $7 \mathrm{kGy}$, (5) $10 \mathrm{kGy}$, (6) $15 \mathrm{kGy,}$ (7) $20 \mathrm{kGy}$, (8) $3 \mathrm{kGy}$. (b) 1-7 : immunoblotting of PSA ( $3 \mathrm{kGy}$ ) to $\mathrm{p}-\mathrm{IgG}, 8$ : immunoblotting of PSA to pig-allergic patients' serum. Arrow indicates the aggregated band of PSA.

by formation of radiolytic products/free radicals indirectly from water (Jeon et al., 2002). Those radicals are known to attack the aromatic and thiol site more than other residues in a protein (Lee and Byun, 2003). Irradiation can break protein molecule down to smaller molecules or aggregate to form larger molecules (Davies and Delsignore, 1987). This result corresponded to the changes of other irradiated proteins such as $\beta$-lactoglobulin (Lee et al., 2001), bovine and porcine plasma protein (Lee et al., 2003), and ovalbumin (Lee et al., 2007). These irradiated proteins were also broken down or coagulated by gamma irradiation treatment. Filail-Mouhim et al. (1997) reported that low-molecular-weight peptides occur by disulfide-bond and peptide-bond cleavage of protein by free radicals generated from gamma irradiation. Kume and Matsuda (1995) reported that production of molecules with high-molecular-weight by gamma irradiation is induced by exposure of hydrophobic sites. For testing reactivity against intact PSA and gamma-irradiated PSA, immunoblotting technique was used (Fig. 3). The gammairradiated PSA solution at 3 to $20 \mathrm{kGy}$ did not recognize anti-PSA IgG and patient's serum. These results indicated that PSA did not recognize the IgG and patient's serum because of structural changes of PSA epitope by gamma irradiation.

\section{Changes in allergenicity of gamma-irradiated PSA}

The changes in allergenicity to gamma-irradiated PSA solution $(3,5,7,10,15$, and $20 \mathrm{kGy})$ were investigated. Binding ability of PSA treated with gamma irradiation to p-IgG sharply was decreased to less than $30 \%$ when PSA solution was treated with a dose of $3 \mathrm{kGy}$ (Fig. 4). The binding ability was about $25 \%$ at $15 \mathrm{kGy}$ and $20 \mathrm{kGy}, 27$, 23 , and $28 \%$ at 3,5 , and $7 \mathrm{kGy}$, respectively (Fig. 4). The ability of gamma-irradiated PSA solution (3, 10, and 20 $\mathrm{kGy}$ ) to bind serum from allergic patient to pork was decreased more to 15,11 , and $19 \%$ as compared with pIgG (Fig. 5). Both results (Fig. 4 and 5) showed no significant differences among irradiated samples. The gamma irradiation was proved to cause reduction in the number of epitopes by the denaturation of the protein such as fragmentation or conformational release of the molecule or aggregation among the molecules (Filail-Mouhim et al., 1997; Kume et al., 1994). In the case of bovine serum albumin (BSA), a similar result was obtained. Kume and Matsuda (1995) reported that reactivity of BSA to antiBSA antibody by gamma radiation was diminished at 4

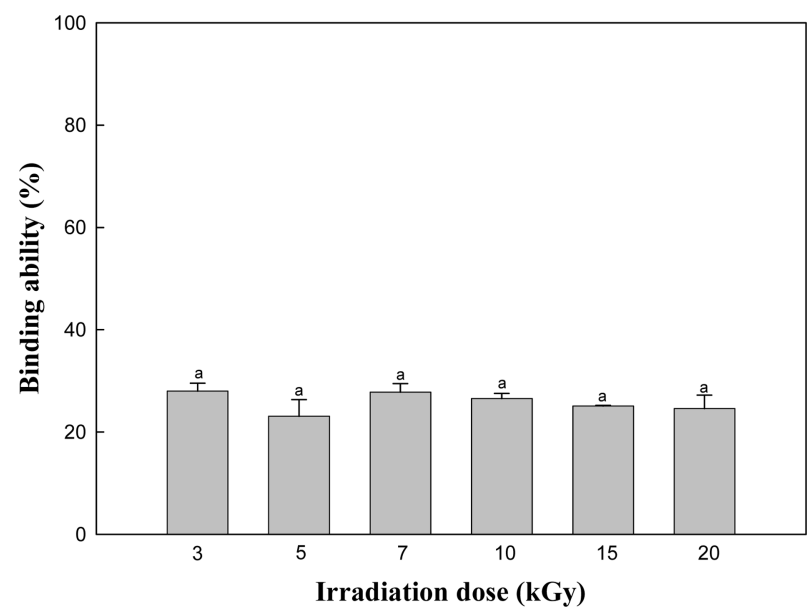

Fig. 4. Binding ability of goat p-IgG to PSA treated with gamma irradiation. Data were no significant difference between sample means. 


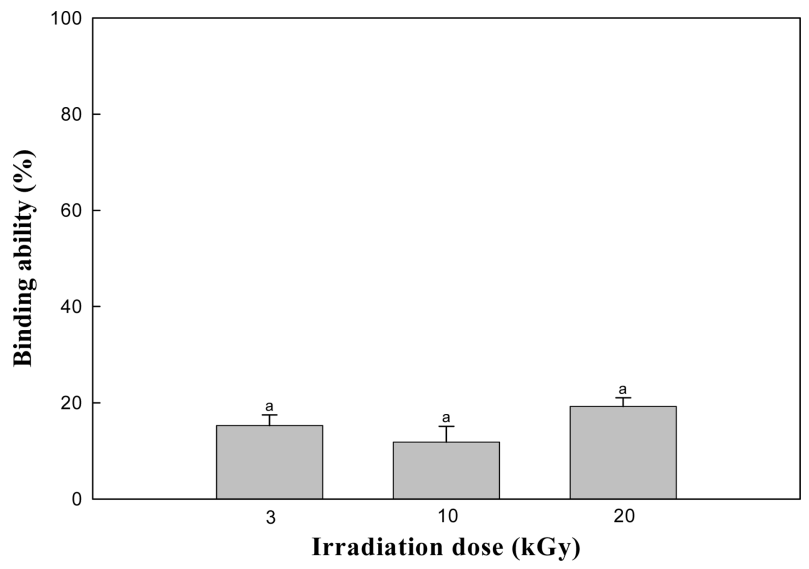

Fig. 5. Binding ability of pig-allergic patient's serum to PSA treated with gamma irradiation. Data were no significant difference between sample means.

kGy. They reported that the reduction in the antigenicity of BSA following gamma irradiation was caused by the destruction of secondary structure and the exposed the hydrophobic amino acids. Thus, our results indicated that gamma irradiation caused the reduction in allergenicity of PSA because of changes of IgG- and IgE-binding epitopes of PSA by modification of structure. Other food allergens have been also studied for reducing their allergenicity by gamma irradiation.; Lee et al. (2000) reported that major shrimp allergen, tropomyosin, was coagulated by irradiation and its antigenicity reduced over $80 \%$ at $10 \mathrm{kGy}$. Cho et al. (2001) showed that allergenicity of $\beta$-lactoglobulin and $\alpha$-lactalbumin of major cow's milk allergen was markedly decreased depending upon increase in doses over $3 \mathrm{kGy}$ because of epitope destruction by gammairradiation. In case of garlic, structural change of irradiated allivin solution was observed by UV spectrum and this result showed that gamma irradiation could reduce the allergenic reaction of the allivin in solution state (Kim et al., 2002). Therefore, PSA modification by gamma irradiation may be applicable not only for the prevention and treatment of pork allergy, but also for the production of hypoallergenic pork product.

\section{Acknowledgment}

This work was supported by the Korea Science and Engineering Foundation (KOSEF) grant funded by the Korea government (MOST) (No. 2006-01328).

\section{References}

1. Ayuso, S., Lehrer, S. B., Tanaka, L., Ibanez, M. D., Pascual,
C., Burks, A. W., Sussman, G. L., Gordburg, B., Lopez, M., and Reese, G. (1999) IgE antibody response to vertebrate meat proteins including tropomyosin. Ann. Allergy Asthma Immunol. 83, 399-405.

2. Bohler, E., Scjafer, T., Ruhdorfer, S., Weigl, L., Wessner, D., Heinrich, J., Filipiak, B., Wichmann, H. E., and Ring, J. (2001) Epidemiology of food allergy in adults (in German). Allergo J. 10, 318-319.

3. Byun, M. W., Kim, J. H., Lee, J. W., Park, J. W., Hong, C. S., and Kang, I. J. (2000) Effects of gamma irradiation on the conformational and antigenic properties of a heat-stable major allergen in brown shrimp. J. Food Prot. 63, 940-944.

4. Cho, K. H., Yook, H. S., Lee, J. W., Lee, S. Y., and Byun, M. W. (2001) Changes of binding ability of milk-hypersensitive patients' IgE to gamma-irradiated milk proteins. J. Korean Soc. Food Sci. Nutr. 30, 505-509.

5. Davies, K. J. and Delsignore M. E. (1987) Protein damage and degradation by oxygen radicals: III. Modification of secondary and tertiary structure. J. Biol. Chem. 262, 9908-9913.

6. Filail-Mouhim, A., Audette, M., St-Louis, M., Thauvette, L., Denoroy, L., Penin, F., Chen, X., Rouleau, N., Le Caer, J. P., Rossier, J., Potier, M., and Le Maire, M. (1997) Lysozyme fragmentation induced by ã-radiolysis. Int. J. Radiat. Biol. 72, 63-70.

7. Fiocchi, A., Restani, P., Riva, E., and Qualizza, R. (1995) Meat Allergy: I-Specific IgE to BSA and OSA in atopic, beef sensitive children. J. Ame. College Nutr. 14, 239-244.

8. Fiocchi, A., Restani, P., Riva, E., Mirri, G. P., Santini, I., Bernardo, L., and Galli, C. L. (1998) Heat treatment modifies the allergenicity of beef and bovine serum albumin. Allergy 53, 798-802

9. Han, G. D. (2006) Heat and High-Pressure Treatments on In Vitro Digestibility and Allergenicity of Beef Extract. Food Sci. Biotechnol. 15, 523-528.

10. Iikura, Y., Imai, Y., Imai, T., Akasawa, A., Fujita, K., Hoshiyama, K., Nakura, H., Kohno, Y., Koike, K., Okudaira, H., and Iwasaki, E. (1999) Frequency of immediate-type food. Allergy in children in Japan. Int. Arch. Allergy Immunol. 118, 251-252.

11. Jeon, G. R., Lee, J. W., Byun, M. W., and Lee, S. Y. (2002) Reduced allergenicities of irradiated egg white ovalbumin determined by skin prick test and ELISA inhibition test. Pediatr. Allergy Respir. Dis. 22, 711-719.

12. Johansson, S. G. O., Hourihane, J. O., Bousquet, J., Bruijnzeel-Koomen, C., Dreborg, S., Haahtela, T., Kowalski, M. L., Mygind, N., Ring, J., and Van Cauwenberge, P. (2001) A revised nomenclature for allergy. An EAACI position statement from the EAACI nomenclature task force. Allergy 56, 813-824.

13. Kanny, G., De Hautecloque, C., and Moneret-Vautrin, D. A. (1998) Food anaphylaxis to bovine serum albumin. $J$. Allergy Clin. Immun. 101, 137-139.

14. Kim, M. R., Seo, J. H., Lee, J. W., Yook, H. S., Kim, M. J., and Byun, M. W. (2002) Effect of gamma irradiation on the conformational changes of garlic (Allium sativum) protein, allivin. J. Korean Soc. Food Sci. Nutr. 31, 723-727. 
15. Kim, S. M., Park, J. G., Kim, K. B. W. R., Saeki, H., Nakamura, A., Lee, J. W., Byun, M. W., and Ahn, D. H. (2008) Changes in the allergenicity of saeujeot by fermentation. Food Sci. Biotechnol. 17, 919-924.

16. Kume, T. and Matsuda, T. (1995) Changes in structural and antigenic properties of proteins by radiation. Radiat. Phys. Chem. 46, 225-231.

17. Kume, T., Ishii, T., and Matsuda, T. (1994) Immunochemical identification of irradiated chicken eggs. J. Sci. Food Agric. 65, 1-4.

18. Laemmli, U. K. (1970) Cleavage of structural proteins during the assembly of the head of bacteriophage T4. Nature 227, 680-685.

19. Lee, J. W. and Byun, M. W. (2003) Food irradiation technology and the structural changes of food allergen by irradiation. Pediatr. Allergy Respir. Dis. 23, 16-23.

20. Lee, J. W., Kim, J. H., Sung, C. K., Kang, K. O., Shin, M. G., and Byun, M. W. (2000) The changes of allergenic and antigenic properties of major allergen(Pen a 1) of brown shrimp (Penaeus aztecus) by gamma irradiation. Korean J. Food Sci. Technol. 32, 822-827.

21. Lee, J. W., Kim, J. H., Yook, H. S., Kang, G. O., Lee, S. Y., Hwang, H. J., and Byun, M. W. (2001) Effects of gamma radiation on the allergenic and antigenic properties of milk proteins. J. Food Prot. 64, 272-276.

22. Lee, J. W., Park, J. H., Kim, C. J., and Shin, H. K. (1998a) Monitoring thermally induced conformational changes in bovine muscle myosin solution by competitive indirect enzyme-linked immunosorbent assay (Ci-ELISA). Int. J. Food Sci. Technol. 33, 411-418.

23. Lee, J. W., Park, J. H., Kim, S. B., Kim, C. J., Hyun, C. K., and Shin, H. K. (1998b) Application of competitive indirect enzyme-linked immunosorbent assay (Ci-ELISA) for monitoring the degree of frozen denaturation of bovine myosin. Int. J. Food Sci. Technol. 33, 401-410.

24. Lee, J. W., Seo, J. H., Kim, J. H., Lee, S. Y., and Byun, M. W. (2007) Comparison of the changes of the antigenicities of a hen's egg albumin by a gamma and an electron beam irradiation. Radiat. Phys. Chem. 76, 879-885.

25. Lee, S. H., Lee, S. H., and Song, K. B. (2003) Effects of gamma-irradiation on the physicochemical properties of porcine and bovine blood plasma proteins. Food Chem. 82, 521526.

26. Llatser, R., Polo, F., De La Hoz, F., and Guillaumet, B. (1998) Alimentary allergy to pork. Crossreactivity among pork kidney and pork and lamb gut. Clin. Exp. Allergy 28, 1021-1025.

27. Moon, E. K., Bae, H. C., Renchinthand, G., and Nam, M. S. (2007) The relationship between food allergen sensitization and allergic disease childhood. Korean J. Food Sci. Ani. Resour. 27, 337-344.

28. Restani, P., Velona, T., Plebani, A., Ugazio, A. G., Poiesi, C., Murano, A., and Galli, C. L. (1995) Evaluation by SDSPAGE and immunoblotting of residual antigenicity in hydrolysed protein formulas. Clin. Exp. Allergy 25, 651-658.

29. Spitzauer, S., Pandjaitan, B., Muhl, S., Ebner, C., Kraft, D., Valenta, R., and Rumpold, H. (1997) Major cat and dog allergens share IgE epitopes. J. Allergy Clin. Immunol. 99, 100106.

30. Spitzauer, S., Pandjaitan, B., Soregi, G., Muhl, S., Ebner, C., Kraft, D., Valenta, R., and Rumpold, H. (1995) IgE crossreactivities against albumins in patients allergic to animals. J. Allergy Clin. Immunol. 96, 951-959.

31. Towbin, H. T., Staehelin, T., and Gordon, J. (1979) Electrophoretic transfers of proteins from polyacrylamide gels to nitrocellulose sheets: procedure and some applications. Proc. Natl. Acad. Sci. USA 76, 4350-4354.

32. Wahn, U., Peters, T. J., and Siraganian, R. P. (1981) Allergenic and antigenic properties of bovine serum albumin. Mol. Immunol. 18, 19-28.

33. Wang, C. H., Kou, S. K., and Chen, H. L. (2002) Porcine serum albumins sandwich ELISA for determining the cooking temperature of cured ground pork. Taiwanese J. Agric. Chem. Food Sci. 40, 197-204.

34. WHO (1999) High-dose irradiation: wholesomeness of food irradiation with doses above $10 \mathrm{kGy}$. Report of Joint FAO/ IAEA/WHO Study Group. WHO Technical Report Series 890, World Health Organization, Geneva.

(Received 2009.12.19/Revised 2010.4.26/Accepted 2010.5.6) 